\title{
Additional new species of Filistatidae (Aranei) from Iran
}

\section{Аополнительные новые виды пауков семейства Filistatidae (Aranei) из Ирана}

\author{
Yuri M. Marusik ${ }^{1,2,3}$, Alireza Zamani ${ }^{4}$ \\ Ю.М. Марусик ${ }^{1,2,3}$, А. Замани ${ }^{4}$
}

\footnotetext{
${ }^{1}$ Institute for Biological Problems of the North RAS, Portovaya Str. 18, Magadan 685000, Russia. E-mail: yurmar@mail.ru

${ }^{2}$ Zoological Museum, University of Turku, FI-20014 Turku, Finland.

${ }^{3}$ Far Eastern Federal University, Sukhanova 8, Vladivostok 690950, Russia.

${ }^{4}$ School of Biology, College of Sciences, University of Tehran, Tehran, Iran. E-mail: zamani.alireza5@gmail.com

${ }^{1}$ Институт биологических проблем Севера ДВО РАН, Портовая 18, Магадан 685000.

3 Дальневосточный Федеральный университет, Суханова 8, Владивосток, 690950, Россия.
}

KEY WORDS: Araneae, fauna, new species, Pritha, Filistata, Filistatinae, Prithinae.

КЛЮЧЕВЫЕ СЛОВА: Araneae, фауна, новый вид, Pritha, Filistata, Filistatinae, Prithinae.

ABSTRACT. Two new species of Filistatidae are described from Iran: Filistata maguirei sp.n. $\left(\mathrm{O}^{\top}+\right)$ from the surroundings of the Geno Biosphere Reserve (Hormozgan Province) and Pritha garfieldi sp.n. ( $\sigma_{+}^{7}$ ) from the southern macroslopes of the Alborz Mountains (Tehran Province). The subfamily Prithinae is recorded for the first time in Iran and the number of Iranian genera and species of Filistatidae is increased to four and nine; this is the highest species-richness for this family in the Western Palaearctic, and the highest genera-richness in the entire Palaearctic.

РЕЗЮМЕ. Описаны два новых вида филистатид из Ирана: Filistata maguirei sp.n. ( $\left.{ }^{7}+\right)$ из Geno Biosphere Reserve (пров. Хормозган) и Pritha garfieldi

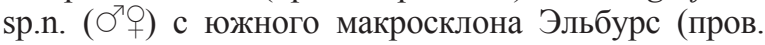
Тегеран). Подсемейство Prithinae впервые указывается для Ирана. Общее число родов и видов в Иране возросло до 4 и 9 соответственно, что делает фауну страны наиболее богатой в плане видового разнообразия в Западной Палеарктике и самой богатой в Палеарктике по числу зарегистрированных родов.

\section{Introduction}

Filistatidae is a relatively small, globally-distributed family currently comprising 121 extant species within 18 genera [World Spider Catalog, 2015]. Although it is assumed that the Middle Eastern and Central Asian fauna should have a high diversity of filistatid spiders, this family remains poorly-studied in these areas. Preliminary studies of this family in Iran were performed by Brignoli [1982]. He described three new species of Zaitunia Lehtinen, 1967 and provided the first Iranian record of Filistata insidiatrix (Forsskål, 1775). Since then, three more species have been reported or described from Iran [Marusik et al., 2014; Marusik \& Zamani, 2015; Zamani et al., 2015]. With seven species belonging to three genera (Filistata Latreille, 1810, Sahastata Benoit, 1968 and Zaitunia), Iran has the highest species diversity of filistatids in the Western Palaearctic. Additionally, the study of new material reveals two more undescribed species, one of which belongs to Pritha Lehtinen, 1967, a genus previously unknown in Iran. These two species are described and illustrated here.

\section{Materials and methods}

Specimens were photographed using an Olympus Camedia E-520 camera attached to an Olympus SZX16 stereomicroscope or to the eye-piece of an Olympus BH2 transaction microscope. Digital images were prepared using "CombineZP" image stacking software. Illustrations of internal genitalia were made after clearing them in a $10 \% \mathrm{KOH}$ aqueous solution and then exposing them to an alcohol/water solution of Chlorazol Black for a few minutes. Lengths of the leg segments were measured on the dorsal side. The description of the palp refers to the left one. All measurements are given in millimetres.

Depositories: Senckenberg Museum, Frankfurt am Main (SMF), Zoological Museum of Moscow State University (ZMMU), Zoological Museum of University of Tehran (ZMUT).

\section{Taxonomy}

Genus Filistata Latreille, 1810

Filistata maguirei sp.n.

Figs 1-14, 32.

TYPES. IRAN: holotype $\sigma^{7}$ and paratype $q$ (SMF), Hormozgan Province: Bandar-e Abbas, area surrounding the Geno Biosphere Reserve, $27^{\circ} 24^{\prime} \mathrm{N}, 56^{\circ} 7^{\prime} \mathrm{E}$, ca $500 \mathrm{~m}$, March 2015 (A. Zamani). 

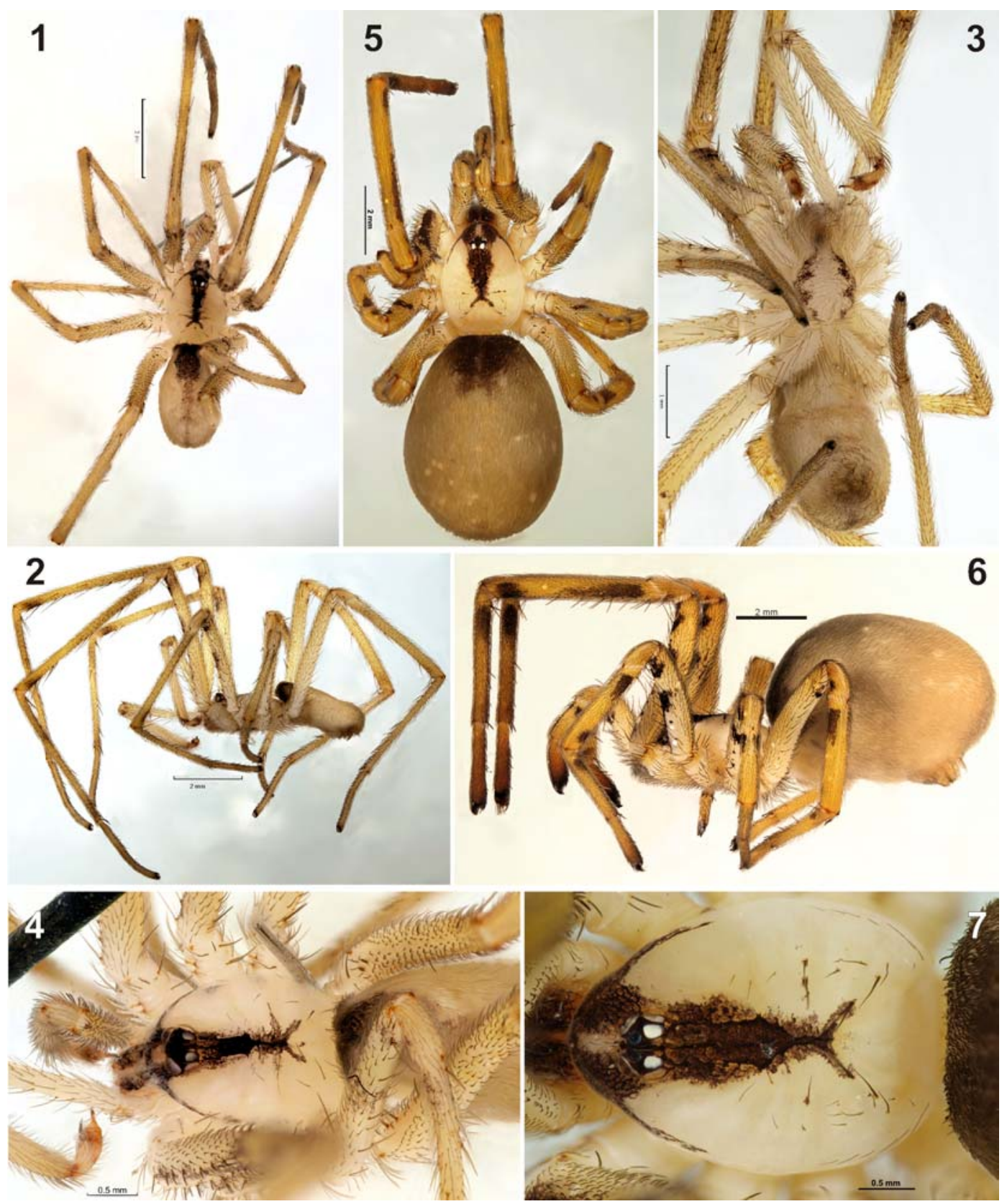

Figs 1-7. Somatic characters of Filistata maguirei sp.n.: male (1-4) and female (5-7): 1, 5 - habitus, dorsal; 2, 6 - habitus, lateral; 3 - habitus, ventral; 4, 7 - prosoma, dorsal.

Рис. 1-7. Соматические признаки Filistata maguirei sp.n.: самец (1-4) и самка (5-7): 1, 5 - габитус, сверху; 2, 6 - габитус, сбоку; 3 - габитус, снизу; 4,7 - головогрудь, сверху.

ETYMOLOGY. This species is named after the American actor and film producer Tobias Vincent "Tobey" Maguire who played the role of Spider-Man in the "Spider-Man" film series.

DIAGNOSIS. The new species differs from other congeners by a dark brown anterior part of abdomen (Figs 1-2, 4-7, 32) in both sexes (uniformly colored in other species). The male of $F$. maguirei sp.n. can be easily distinguished from other congeners by the embolus which has fine ridges and is bent dorsally (Figs
8-10; the embolus of other species has no ridges and the embolus is not bent or is bent ventrally). The female of the new species differs from other East Mediterranean Filistata with a described endogyne by having bean-shaped and not globular receptacles.

COMMENT. Although the new species differ from $F$. insidiatrix, the generotype, by having distinct annulations and spots on the legs in both sexes (lacking or less distinct in most $F$. insidiatrix), lacking a set of long setae on the prolateral side of cymbium, and hav- 

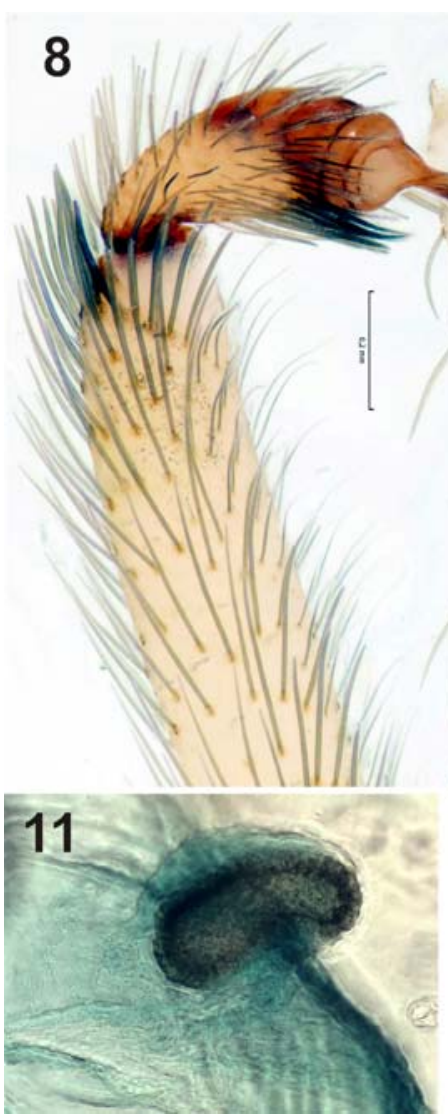
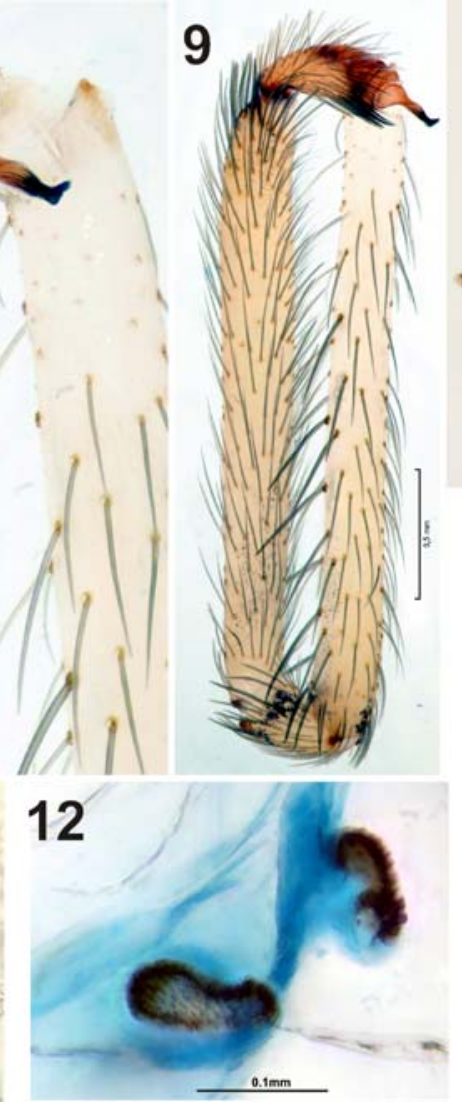
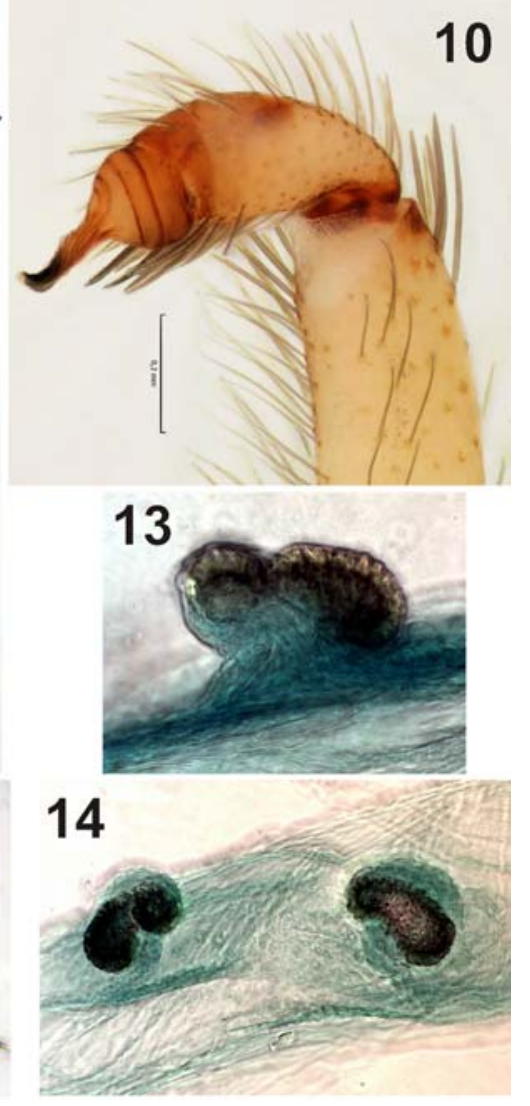

Figs 8-14. Copulatory organs of Filistata maguirei sp.n.: 8 - terminal part of male palp, prolateral; 9 - entire male palp, prolateral; 10 - terminal part of male palp, retrolateral; 11,13 - receptacle, anterior and dorsal; 12,14 - endogyne, latero-anterior and dorsal.

Рис. 8-14. Копулятивные органы Filistata maguirei sp.n.: 8 - верхняя часть пальпы самца, prolateral; 9 - вся пальпа самца, пролатерально; 10 - вершина пальпы самца, ретролатерально; 11, 13 - рецептакула, спереди и сверху; 12,14 - эндогина, сбоку-спереди и сверху.

ing non-globular receptacles [cf. Marusik \& Zonstein, 2014], we placed F. maguirei sp.n. into Filistata because of the presence of distinct fovea, an identical calamistrum in the females, an elongate, slanting clypeus, similar labium and a long male palp. The closely related genus Zaitunia has a similar calamistrum, a shorter, steeper clypeus, a shorter labium and a much shorter male palp [cf. Zonstein \& Marusik, 2015].

DESCRIPTION. Male (holotype). Habitus as shown in Figs 1-2. Total length 5.5. Carapace (Figs 1, 4): 2.1 long, 1.5 wide, with deep inverted Y-shaped fovea; covered with a few short setae; posterior $1 / 3$ with series of setae forming dark submarginal stripe. Eye sizes and interdistances: AME 0.1, ALE 0.21, PLE 0.19, PME 0.13, AME-AME 0.04.

Colour in alcohol: Pale yellow. Carapace with dark brown median band terminating in star-shaped mark; anterior $1 / 3$ with thin, dark marginal stripe; clypeus dark brown with light median band. Sternum with brown margins (Fig. 3). Frontal part of chelicerae dark brown. Legs with a few dark spots and ventrolateral annulations. Palp pale yellow with small dark spot anterodorsally on femur, dark annulation on patella, and dusky spots on tibia. Anterior part of abdomen dark brown.
Spination. All femora with 12-20 thick ventral bristles. Palp: patella v1; tibia and cymbium aspinose. Femora: I-III: d1, p2, r2; IV: d3, p2, r2. Patellae I-IV: v1. Tibiae: I: v10-11; II: v7-9; III-IV: v4-6. Metatarsi: I-II: p1, v7-9; III: v8-9; IV: v9-11. Tarsi: I-II: v7-8; III-IV: v14-18. All tarsi pseudosegmented (with cuticular cracks).

Abdomen: with distinct cribellum.

Male palp as in Figs 8-10; very long, longer than body; femur longer and slightly thinner than tibia with several ventral spines; palpal tibia longer than carapace, covered dorsally and laterally with straight setae and thin, bent setae ventrally. Cymbium subconical, with brush of dense, thick setae ventrally and laterally. Bulb, including embolus, shorter than cymbium; spermophor with two coils; embolic part of bulb helical with one convolution, as long as bulb, basal part with distinct fine longitudinal ridges; tip of embolus bent dorsally.

Female (paratype). Habitus as shown in Figs 5-6, 33. Total length 9.5. Carapace (Figs 5, 7): 3.3 long, 2.4 wide, with distinct pit. Eye sizes and interdistances: AME 0.11, ALE 0.29, PLE 0.23, PME 0.17, AMEAME 0.06 . 

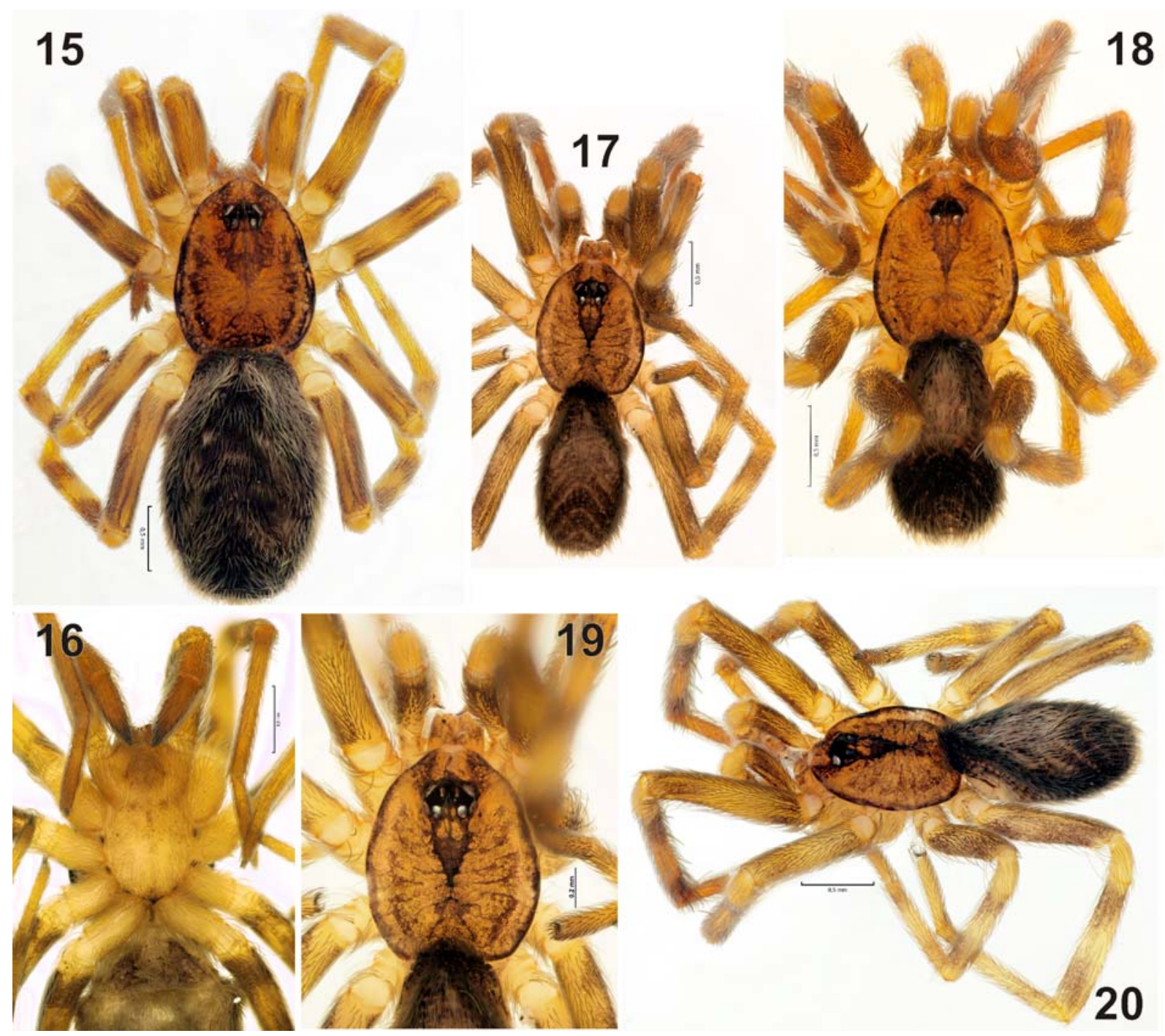

Figs 15-20. Somatic characters of Pritha garfieldi sp.n.: female (15-16) and male (17-20): 15, 17-18 - habitus, dorsal; 16 prosoma and part of abdomen, ventral; 19 - prosoma, dorsal; 20 - habitus, dorsolateral. 18 - holotype.

Рис. 15-20. Соматические признаки Pritha garfieldi sp.n.: самка (15-16) и самец (17-20): 15, 17-18 - габитус, сверху; 16 головогрудь и часть брюшка, снизу; 19 - головогрудь, сверху; 20 - габитус сверху-сбоку. 18 - голотип.

Colour in alcohol: Carapace pale yellow with dark brown median band extended to fovea and terminating in a caret-shaped mark; clypeus dark brown with pale median stripe; anterior $1 / 3$ with dark marginal stripes. Sternum uniformly yellow. Chelicerae dark brown anteriorly. Legs darker than carapace, tarsi and metatarsi I and palpal tarsi brown; all leg segments except tarsi with dark longitudinal or transverse stripes and spots. Anterior part of abdomen dark brown.

Spination. All femora with 1 basodorsal spine and 15-20 thick ventral bristles. Palp: tibia v3-4; tarsus v45. Patellae I-IV: v1. Tibiae: I: v7-9; II: v7-8; III-IV: v4-6. Metatarsi: I-II: v7-8; III-IV: v4-5. Tarsi: I-II: v7-9; III: v10; IV: v12-15.

Endogyne as in Figs 11-14 with pair of unbranched, bean-shaped receptacles on a short, wide stem; recep- tacles separated by more than their width; each receptacle indistinctly subdivided into two parts; cilia of pore-glands very fine, almost indistinct (maybe caused by dissolving in $\mathrm{KOH}$ ).

Leg measurements, $\sigma^{\top}(+)$ :

\begin{tabular}{|l|c|c|c|c|c|c|}
\hline & Femur & Patella & Tibia & Metatarsus & Tarsus & Total \\
\hline Palp & $2.5(1.9)$ & $0.45(1.0)$ & $2.35(1.2)$ & - & $0.45(1.3)$ & $5.75(5.4)$ \\
\hline I & $4.5(4.5)$ & $0.85(1.25)$ & $5.1(4.5)$ & $4.7(3.75)$ & $2.25(2.25)$ & $17.4(16.25)$ \\
\hline II & $3.6(3.25)$ & $0.75(1.1)$ & $3.5(2.8)$ & $3.6(2.5)$ & $2.85(1.6)$ & $14.3(11.25)$ \\
\hline III & $2.9(2.5)$ & $0.75(1.1)$ & $2.7(2.1)$ & $3.0(2.05)$ & $1.6(1.3)$ & $10.95(9.05)$ \\
\hline IV & $4.0(3.75)$ & $0.85(1.25)$ & $3.7(3.05)$ & $4.0(2.7)$ & $2.85(1.5)$ & $15.4(12.25)$ \\
\hline
\end{tabular}

HABITAT. Specimens were collected from under of two large rocks in a dry, mountainous habitat near the road.

DISTRIBUTION. Known only from the type locality in Hormozgan Province. 

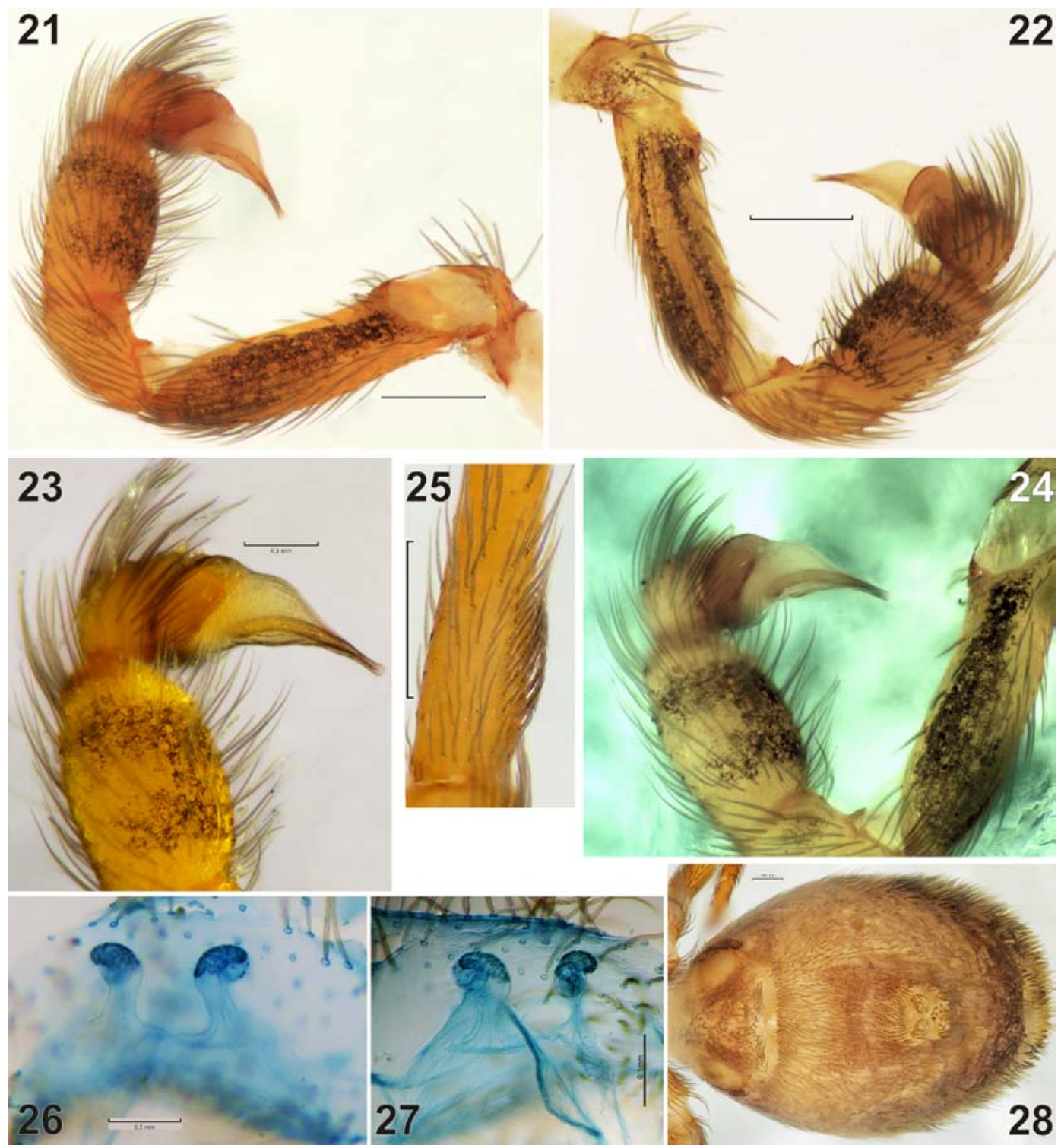

Figs 21-28. Pritha garfieldi sp.n.: 21-22 - male palp, pro- and retrolateral; 23 - terminal part of male palp, prolateral; $24-$ male palp, prolateral; 25 - calamistrum of female; 26, 27 - endogyne, dorsal, and dorsolateral; 28 - female abdomen, ventral. 21-24 holotype male.

Рис. 21-28. Pritha garfieldi sp.n.: 21-22 - пальпа самца, про- и ретролатерально; 23 - вершина пальпы самца, пролатерально; 24 пальпа самца, пролатерально; 25 - каламиструм самки; 26, 27 - эндогина, сверху, и сверху-сбоку; 28 - брюшко самки, снизу. 21-24- голотип.

Genus Pritha Lehtinen, 1967

\section{Pritha garfieldi sp.n.}

Figs 15-31.

TYPES. IRAN: holotype $O^{7}$ (SMF), Tehran Province: Tehran, $35^{\circ} 48^{\prime} \mathrm{N}, 51^{\circ} 27^{\prime} \mathrm{E}$, May 2015 (A. Zamani), and paratypes $10^{7} 1$ क (ZMUT), same data as holotype, and 11 ㅇ 8 juv. (ZMMU, ZMUT), Tehran Province: Southern macroslopes of Alborz Mountains, $35^{\circ} 48^{\prime} 29^{\prime \prime} \mathrm{N}, 51^{\circ} 23^{\prime} \mathrm{E}$, July 2014 (A. Zamani).

ETYMOLOGY. This species is named after the American-English actor Andrew Russell Garfield, who played the role of Spider-Man in "The Amazing Spider-Man" film series.
DIAGNOSIS. The new species is easily distinguished from the generotype Pritha nana (Simon, 1868) by the shape of the receptacle heads. In P. nana, the receptacle is straight with a globular head on a thin stem [Ledoux, 1977: cf. figs 2A-B], whereas in P. garfieldi sp.n., the terminal part of the receptacle is bent laterally and the globular head is not on a distinct stem. The male of the new species is easily distinguished from $P$. nana by having a relatively shorter (diameter/bulb length ratio 2.25 in the new species and 2.4-2.75 in P. nana) and wider bulb (bulb diameter approximately the same diameter as the femur, whereas it is 1.5 times thinner in P. nana) [Ledoux, 1977: cf. figs. 3A-C]. 


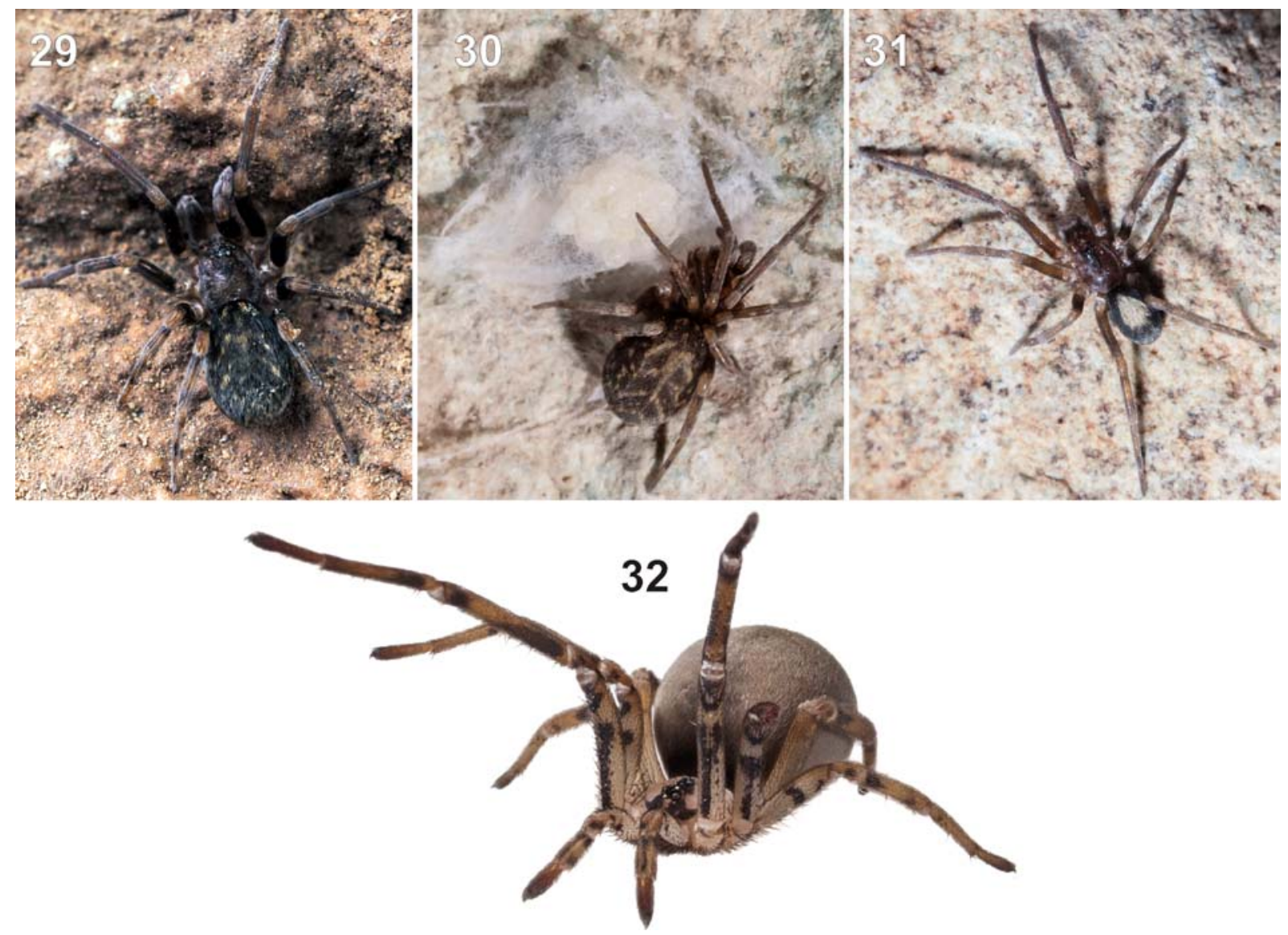

Figs 29-32. Live specimens of Pritha garfieldi sp.n. (29-31) and Filistata maguirei sp.n. (32): 29 - female; 30 - female with egg sac; 31 - male; 32 - aggressive posture of female. Photographs by Ali Mohajeran.

Рис. 29-32. Натурные фотографии Pritha garfieldi sp.n. (29-31) и Filistata maguirei sp.n. (32): 29 — самка; 30 — самка с коконом; 31 - самец; 32 - агрессивная поза самки. Фотографии Ali Mohajeran.

DESCRIPTION. Male (holotype). Total length 2.37. Carapace (Figs 17-20): 1.13 long, 0.93 wide. Eye sizes and interdistances: AME 0.04, ALE 0.11, PLE 0.1, PME 0.06, AME-AME 0.04. Fovea indistinct, carapace with sublateral groove.

Colour in alcohol (Figs 17-20): brown. Carapace yellow with brown pattern: eye area dark, V-shaped dark brown spot starting at posterior eyes and terminating in fovea, anterior part of spot with two oval yellow spots, clypeus yellow with lateral dark bands, sublateral light band and dark margins. Sternum yellow with dark dots between coxa and on posterior edge. Legs and palps yellowish with dark annulations or spots. Abdomen brown with large white spot in anterior half formed by whitish hairs and caret-shaped light stripes in posterior half.

Colour of live specimen (Fig. 31): carapace pattern indistinct, abdomen with droplet-shaped white spot in anterior half; patella lighter than other segments.

Spination. Femora I-II with 1 prolateral bristle; tibia I-III with 1 retrolateral bristle, I with 3 ventral, II with 1 ventral; metatarsi I-II and IV with 2 ventroapical bristles.
Palp as in Figs 21-24, femur subequal in length to patella-cymbium, approximately 4 times longer than wide; tibia swollen, wider than femur, 1.5 longer than wide. Cymbium short, with horseshoe-shaped tip, prolateral part extended. Bulb subconical; spermophor (in prolateral view) very wide, coiling once; both sides of bulb with fine longitudinal ridges.

Female (paratype). Total length 4.48. Carapace 1.26 long, 0.96 wide. Eye sizes and interdistances: AME 0.07, ALE 0.12, PLE 0.08, PME 0.08, AME-AME 0.03, ALE-ALE 0.12, PME-PME 0.08.

Colour in alcohol (Figs 15-16): dark with distinct pattern on carapace that is almost lacking on abdomen. Carapace with dark marginal stripe, light submarginal stripe and lateral dark stripe, both submarginal and lateral stripes U-shaped; median part of carapace behind eyes with triangular dark spot; labium light medially and dark laterally; some specimens with radial stripes.

Legs and palps with dark femora, other segments yellow, lighter than femora and carapace. Spination: metatarsi III and IV with 2 apical ventral spines. Calamistrum occupies proximal $1 / 3$ of metatarsus, comprising three rows of setae (triseriate) (Fig. 25). 
Colour of live specimen (Figs 29-30): carapace uniformly coloured, abdomen with median light stripe (may be absent) and lateral light, slanting stripes; patella lighter than other leg segments.

Endogyne as in Figs 26-27, with 1 pair of receptacles with well-developed heads; receptacle stem separated by 2 diameters, and heads separated from one another by their width; heads subdivided into two parts: round (globular) and tube (sac) like; tube like part bent and directed laterally, densely covered with glands; globular part less densely covered with glands.

Leg measurements, $\sigma^{7}(+)$ :

\begin{tabular}{|l|c|c|c|c|c|c|}
\hline & Femur & Patella & Tibia & Metatarsus & Tarsus & Total \\
\hline Palp & $0.61(0.66)$ & $0.33(0.3)$ & $0.33(0.38)$ & - & $0.14(0.44)$ & $1.41(1.78)$ \\
\hline I & $1.34(1.12)$ & $0.4(0.4)$ & $1.35(1.1)$ & $1.14(0.9)$ & $0.71(0.7)$ & $4.94(4.22)$ \\
\hline II & $1.07(0.9)$ & $0.37(0.32)$ & $1.04(0.7)$ & $0.94(0.7)$ & $0.49(0.48)$ & $3.91(3.1)$ \\
\hline III & $0.86(0.84)$ & $0.36(0.3)$ & $0.8(0.6)$ & $0.94(0.5)$ & $0.46(0.46)$ & $3.42(2.7)$ \\
\hline IV & $1.14(1.14)$ & $0.37(0.4)$ & $1.04(1.0)$ & $1.14(0.8)$ & $0.57(0.5)$ & $4.26(3.84)$ \\
\hline
\end{tabular}

VARIATION. Some female specimens have a distinct abdominal pattern and dark annulations on tibiae and metatarsi.

HABITAT. Specimens were found in large, dusty cribellate webs made around human dwellings, and in only locality, in co-habitation with Zaitunia akhanii Marusik et Zamani, 2015.

DISTRIBUTION. Known only from the type localities in Tehran Province.

REMARKS. This is the first record of the subfamily Prithinae in Iran. To our knowledge, we are providing the first photographic documentation of the egg sac of this genus (Fig. 30). The egg sac was examined using a stereomicroscope, and 18 eggs were found within it.
ACKNOWLEDGMENTS. We are grateful to Pantea Taheri, Hasti Haji-Abolhasan, Hamid Khavanin and Ali Musavi for their help with fieldwork and Ali Mohajeran (Department of Environment) for photographing the live specimens of the new species. The first author thanks Sergei L. Zonstein for advice on the family's taxonomy. The English of the earlier draft was kindly checked and corrected by Sarah Crews.

\section{References}

Brignoli P.M. 1982. Contribution à la connaissance des Filistatidae paléarctiques (Araneae) // Revue Arachnologique. T.4. P.6575.

Ledoux J-C. 1977. Redescription de Pritha nana (Simon) (Araneae, Filistatidae) // Revue Arachnologique. T.1. P.65-74.

Marusik Y.M., Zamani A. 2015. The spider family Filistatidae (Araneae) in Iran // ZooKeys. Vol.516. P.123-135.

Marusik Y.M., Zamani A., Mirshamsi O. 2014. Three new species of mygalomorph and filistatid spiders from Iran (Araneae, Cyrtaucheniidae, Nemesiidae and Filistatidae) // ZooKeys. Vol.463. P.1-10.

Marusik Y.M., Zonstein S.L. 2014. A synopsis of Middle East Filistata (Aranei: Filistatidae), with description of new species from Azerbaijan // Arthropoda Selecta. Vol.23. No.2. P.199205.

World Spider Catalog 2015. World Spider Catalog. Natural History Museum Bern, online at http://wsc.nmbe.ch, version 16, accessed on $8^{\text {th }}$ April 2015.

Zamani A., Mirshamsi O., Marusik Y.M., Moradmand M. 2015. The Checklist of the Spiders of Iran. Version 2015, online at http://www.spiders.ir, accessed on $8^{\text {th }}$ April 2015.

Zonstein S., Marusik Y.M. 2015 (in press). A revision of the spider genus Zaitunia (Araneae, Filistatidae) // European Journal of Taxonomy.

Responsible editor K.G. Mikhailov 